\title{
Seasonal Variation of Some Trace Element and Heavy Metal Concentrations in a Turkish Stream
}

\author{
Saliha Dorak ${ }^{1}$, Hakan Çelik ${ }^{2 *}$ \\ ${ }^{1}$ Department of Soil Science and Plant Nutrition, Institute of Natural and Applied Sciences, \\ Bursa Uludag University, Bursa/Turkey \\ ${ }^{2}$ Department of Soil Science and Plant Nutrition, Faculty of Agriculture, Bursa Uludag University, Bursa/Turkey
}

Received: 16 February 2018

Accepted: 15 December 2018

\begin{abstract}
Nilüfer stream in Bursa, Turkey, is important for being a huge resource for irrigation and also the wastewater discharge point of many treatment plants. There are lots of factories dealing with textile and food industries and also municipal waste treatment facilities that directly discharge their wastewaters into the stream and may lead to pollution. In this research, we aimed to determine the seasonal variation of some trace element and heavy metal concentrations of Nilüfer stream and the treatment plants. Water samples were taken from the treatment plants and from the stream that the treatment plants discharged to at four different periods during August 2013 to May 2014. Discharges from the treatment plants affected the quality of the stream negatively $(\mathrm{p}<0.01)$ and varied depending on the sampling periods and also depending on the processed products at the factories and also their discharges from the treatment plants. Although the $\mathrm{Zn}, \mathrm{Al}, \mathrm{Ni}, \mathrm{Pb}$, and Co concentrations of the water samples were found to be under the limits of the World Health Organization (WHO), the Food and Agriculture Organization of the United Nations (FAO) and Treated Water (TW), concentrations of especially $\mathrm{Fe}, \mathrm{Cu}, \mathrm{Mn}, \mathrm{Cd}$ and $\mathrm{Cr}$ were found to be over the limitations of TW.
\end{abstract}

Keywords: heavy metal, toxicity, wastewater discharge, water pollution

\section{Introduction}

Water is a key element for the existence of living organisms and these organisms provide the surface water and groundwater resources to sustain their vital activities [1]. But since two hundred years ago, our natural resources have been polluted as a result of

*e-mail: hcelik@uludag.edu.tr rapid population growth, industrial development and unconscious agricultural activities [1-2]. For this reason, the use of irrigational or industrial purposes of the water is restricted [1]. Waters including high toxic quantities of ingredients used for household activities, irrigation or industrial purposes without any treatment bring some health and environmental problems [3-7]. Therefore, it is important to take precautions due to the foreign material type and their high concentrations in the water [8-9]. It was thought that nature could cope with these 
polluters that formed in the early days. But it did not work out this way, and these polluters have begun to negatively impact nature and all living beings [10]. For this reason, studies have been started by researchers to understand and prevent the causes of these pollutants [1, $6,7,11-12]$.

Bursa is one of the biggest and most important cities of Turkey in terms of agriculture and industry. A considerable increase in the population of Bursa Province has occurred in recent years due to migration, resulting in an increase of residential areas against fertile agricultural lands, and this has also resulted in the increase of various wastes [2, 12]. Nilüfer Stream, with its several tributaries, reaches to an extent of approximately $168 \mathrm{~km}$ and is an important water resource of Bursa, which supplies water to irrigation of agricultural sites and for drinking [2-12]. The stream basin covers $1540 \mathrm{~km}^{2}$, and over $53.8 \%$ of the basin is used for agricultural purposes [2, 12-13]. The stream is not only significant for irrigating the agricultural lands but also is important as being the discharge point for many industries [2, 14]. In recent years, it has been contaminated by the industrial and domestic wastewater discharges. Especially in summer season water levels in tributaries decrease due to evaporation and due to the use of the water for agricultural irrigation purposes, and in addition, the increases in sewerage flow lead to the deterioration of water quality and the deterioration of human health [13, 15-16].

In this research we aimed to determine some trace element and heavy metal contents of the stream and water samples of the treatment plants in a year's time. Analysis results were compared with international organizations' standards. The World Health Organization (WHO) [17] was used for evaluating the waters for drinking and human consumption. The results were evaluated for irrigation purposes with the standards of the Food and Agriculture Organization of the United Nations (FAO) [18], which includes the same values of Turkish National Water Pollution Control Regulation and Quality Criteria for Irrigation Water. The results were also evaluated with the standards of Treated Water (TW) [19] in order to clarify the treatment plant performances treating wastewaters for irrigation and human consumption.

\section{Materials and Methods}

Nilüfer Stream, which flows within the boundaries of Bursa city in northwestern Turkey $\left(40^{\circ} 11^{\prime} \mathrm{N}\right.$ and $\left.29^{\circ} 04^{\prime} \mathrm{E}\right)$ and some wastewater treatment plants that discharge to this stream comprise the main materials of our research.

We collected the samples from the stream and from the wastewater treatment plants in order to determine the trace element and heavy metal concentrations of the stream in four periods (P1: summer - August 2013; P2: autumn - November 2013; P3: winter - February 2014; and P4: spring - May 2014). Sampling points of the waters and their abbreviations used in the research are shown in Fig. 1 and Table 1.

Water samples were collected in $1000 \mathrm{~mL}$ polyethylene bottles from the mid-point of the stream at $15-20 \mathrm{~cm}$ depth. Sampling bottles were previously washed with the sampling water then filled with the water to the upper point. Water samples were filtered through Whatman filter paper and acidified to $\mathrm{pH} 2$ with nitric acid $\left(\mathrm{HNO}_{3}\right)$ (ultrapure, Merck) in order to minimize precipitation and adsorption on the walls of the containers [20]. All of the analyses were completed within two days based on the standard methods [21]. For determining the trace elements and heavy metal

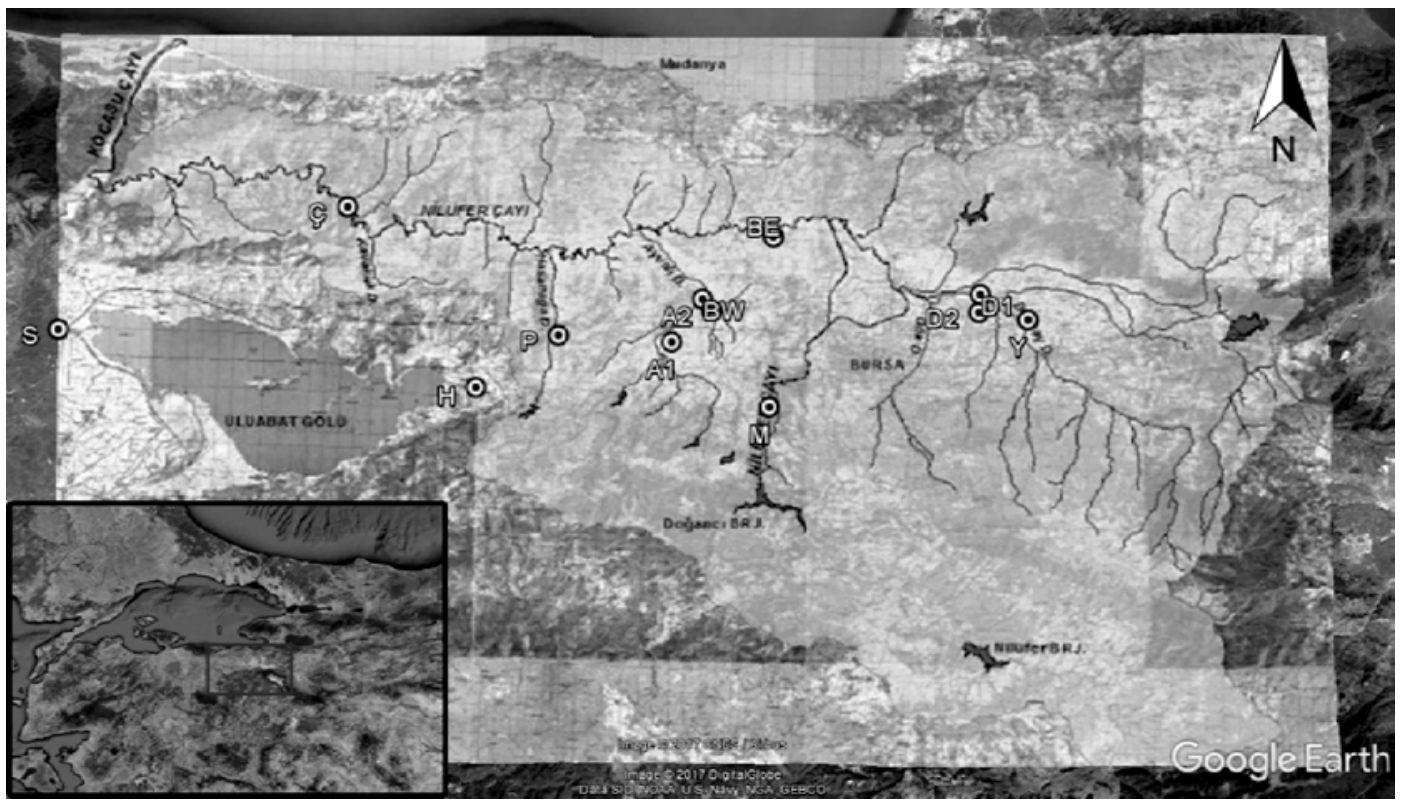

Fig. 1. Sampling points. 
Table 1. Sampling points and abbreviations.

\begin{tabular}{|c|c|c|}
\hline No & Sampling Point & $\begin{array}{c}\text { Abbre- } \\
\text { viation }\end{array}$ \\
\hline \multicolumn{3}{|c|}{ Wastewater treatment plants } \\
\hline 1 & Sütaş Dairy Inc. Water Treatment Plant & S \\
\hline 2 & $\begin{array}{c}\text { Penguen Food Industry Inc. Treatment } \\
\text { Plant }\end{array}$ & P \\
\hline 3 & S.S. Yeşil Environmental Treatment Plant & Y \\
\hline 4 & Buski East Wastewater Treatment Plant & BE \\
\hline 5 & Buski West Wastewater Treatment Plant & BW \\
\hline \multicolumn{3}{|c|}{ Tributaries of the Nilüfer Stream } \\
\hline 6 & Çayönü village & Ç \\
\hline 7 & Ayvalı stream $1^{\text {st }}$ point & A1 \\
\hline 8 & Ayval1 stream $2^{\text {nd }}$ point & A2 \\
\hline 9 & Hasanağa stream & H \\
\hline 10 & Misi stream & M \\
\hline 11 & Deliçay stream $1^{\text {st }}$ point & D1 \\
\hline 12 & Deliçay stream $2^{\text {nd }}$ point & D2 \\
\hline
\end{tabular}

concentrations, $8 \mathrm{~mL}$ aliquots were taken from the water samples and were digested, adding $4 \mathrm{~mL}$ of $\mathrm{HNO}_{3}$ in a microwave oven Berghof MWS 2 (Germany) [22]. Iron $(\mathrm{Fe})$, copper $(\mathrm{Cu})$, manganese $(\mathrm{Mn})$, zinc $(\mathrm{Zn})$, aluminum $(\mathrm{Al})$, lead $(\mathrm{Pb})$, nickel $(\mathrm{Ni})$, chromium $(\mathrm{Cr})$, cobalt $(\mathrm{Co})$, and cadmium $(\mathrm{Cd})$ concentrations of the digested samples were determined by inductively coupled plasma-optical emission spectrometry (ICP-OES)
(Perkin Elmer Optima 2100DV, USA) [7, 21-22]. Data taken from the analysis were subjected to analysis of variance (ANOVA) and the mean values were compared using least significant difference (LSD) multiple range test with the computer program MINITAB 17.1.0.0 (Minitab INC., State College, Pennsylvania, USA).

\section{Results and Discussion}

Seasonal variations of the trace element and heavy metal concentrations of the water samples taken from the tributaries of the stream are shown in Table 2.

Trace element and heavy metal concentrations of the waters taken from the tributaries of the stream differ, depending on the sampling periods $(p<0.01)$. Among the trace elements and heavy metals, $\mathrm{Zn}, \mathrm{Pb}$, $\mathrm{Co}$ and $\mathrm{Al}$ concentrations of the waters were found to be under the limits of WHO, FAO and TW throughout all periods. However, concentrations of $\mathrm{Fe}, \mathrm{Mn}$, and $\mathrm{Cd}$ according to WHO safe limits; Mn concentrations according to $\mathrm{FAO}$ and $\mathrm{Fe}, \mathrm{Cu}, \mathrm{Mn}, \mathrm{Ni}$, and $\mathrm{Cr}$ values of the waters according to TW limitations were found to be high at one or more of the sampling periods (Table 2). The variations between the trace elements and heavy metal concentrations of the samples were thought to be related to natural causes, such as temperature, $\mathrm{pH}$, redox reactions, water flow, microorganism activity, climate, type and amount of precipitation [1, 23]. Variations may also be from anthropogenic reasons or the processed products at the factories and also their discharges from treatment plants [1, 23]. The water quality problems experienced by the stream were also attributed to the direct discharges of domestic and

Table 2. Seasonal variations of the trace element and heavy metal concentrations of the waters taken from the tributaries of Nilüfer Stream.

\begin{tabular}{|c|c|c|c|c|c|c|c|c|c|c|c|c|}
\hline \multirow{3}{*}{$\begin{array}{c}\text { WHO* }^{*} \\
0.3\end{array}$} & \multirow{3}{*}{$\begin{array}{c}\mathrm{FAO}^{* *} \\
5.0\end{array}$} & \multirow{3}{*}{$\begin{array}{l}\mathrm{TW}^{* * *} \\
0.33\end{array}$} & \multirow{3}{*}{$\begin{array}{l}\text { Parameters } \\
\mathrm{Fe}\left(\mathrm{mg} \mathrm{L}^{-1}\right)\end{array}$} & \multicolumn{8}{|c|}{ Periods } & \multirow{3}{*}{$\begin{array}{c}\begin{array}{c}\text { LSD } \\
(\mathrm{p}<0.01)\end{array} \\
0.008\end{array}$} \\
\hline & & & & \multicolumn{2}{|c|}{$\begin{array}{c}1^{\text {th }} \\
\text { (Summer) }\end{array}$} & \multicolumn{2}{|c|}{$\begin{array}{c}2^{\text {nd }} \\
\text { (Autumn) }\end{array}$} & \multicolumn{2}{|c|}{$\begin{array}{c}3^{\text {rd }} \\
\text { (Winter) }\end{array}$} & \multicolumn{2}{|c|}{$\begin{array}{c}4^{\text {th }} \\
\text { (Spring) }\end{array}$} & \\
\hline & & & & 0.73 & $\mathrm{C}$ & 0.48 & $\mathrm{D}$ & 1.42 & A & 0.76 & B & \\
\hline 2.0 & 0.2 & 0.03 & $\mathrm{Cu}\left(\mathrm{mg} \mathrm{L}^{-1}\right)$ & 0.04 & B & 0.04 & $\mathrm{C}$ & 0.05 & A & 0.03 & D & 0.001 \\
\hline 3.0 & 2.0 & 0.12 & $\mathrm{Zn}\left(\mathrm{mg} \mathrm{L}^{-1}\right)$ & 0.04 & D & 0.04 & $\mathrm{C}$ & 0.05 & B & 0.09 & A & 0.0001 \\
\hline 0.5 & 0.2 & 0.05 & $\operatorname{Mn}\left(\mathrm{mg} \mathrm{L}^{-1}\right)$ & 1.00 & B & 0.86 & $\mathrm{D}$ & 1.08 & A & 0.97 & $\mathrm{C}$ & 0.014 \\
\hline- & 5.0 & - & $\mathrm{Al}\left(\mathrm{mg} \mathrm{L}^{-1}\right)$ & 0.82 & $\mathrm{BC}$ & 2.42 & A & 0.89 & B & 0.89 & $\mathrm{C}$ & 0.084 \\
\hline- & 0.2 & 0.06 & $\mathrm{Ni}\left(\mathrm{mg} \mathrm{L}^{-1}\right)$ & 0.02 & $\mathrm{D}$ & 0.02 & $\mathrm{C}$ & 0.07 & A & 0.04 & B & 0.001 \\
\hline 10 & 2000 & 190 & $\mathrm{~Pb}\left(\mu \mathrm{g} \mathrm{L}^{-1}\right)$ & 2.57 & A & 1.86 & $\mathrm{D}$ & 2.17 & $\mathrm{C}$ & 2.29 & B & 0.078 \\
\hline 50 & 100 & 20 & $\mathrm{Cr}\left(\mu \mathrm{g} \mathrm{L}^{-1}\right)$ & 15.22 & $\mathrm{C}$ & 26.48 & A & 26.40 & A & 25.32 & B & 0.244 \\
\hline- & 50 & 50 & $\mathrm{Co}\left(\mu \mathrm{g} \mathrm{L}^{-1}\right)$ & 3.24 & B & 5.29 & A & 2.99 & $\mathrm{D}$ & 3.19 & $\mathrm{C}$ & 0.041 \\
\hline 3 & 10 & - & $\mathrm{Cd}\left(\mu \mathrm{g} \mathrm{L}^{-1}\right)$ & 4.95 & B & 5.50 & A & 4.83 & $\mathrm{C}$ & 4.60 & D & 0.079 \\
\hline
\end{tabular}

Notes. The differences between values by different capital letters are significant $(\mathrm{p}<0.01)$.

${ }^{*}$ Max: permissible limit for drinking purpose/human consumption (17)

${ }^{* *}$ Recommended maximum concentration for irrigation/crop production (18)

${ }^{* * *}$ Average quality characteristics of Treated Wastewaters (TW) used for irrigation (19) 


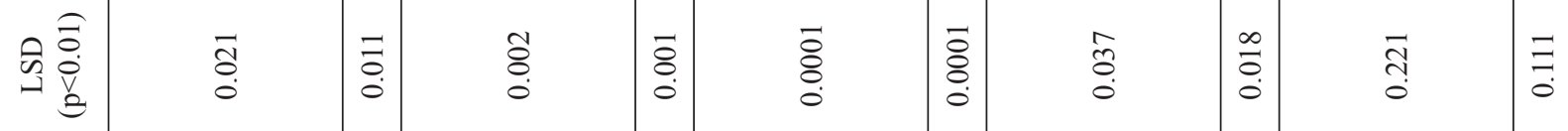

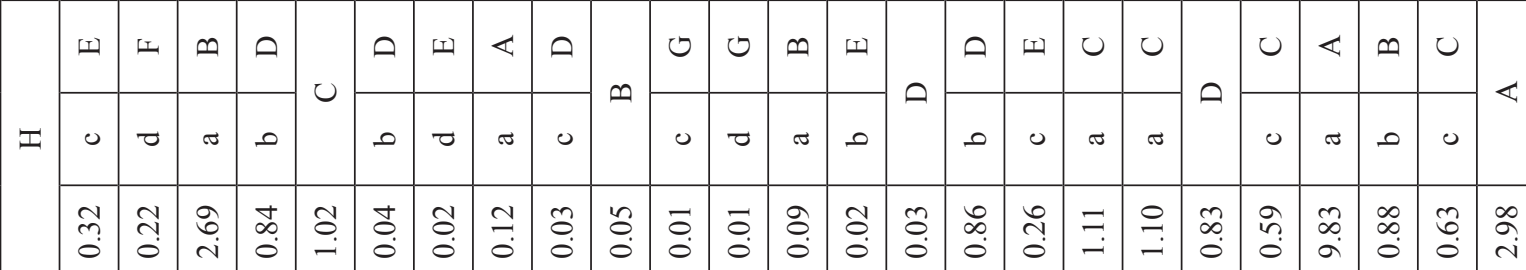

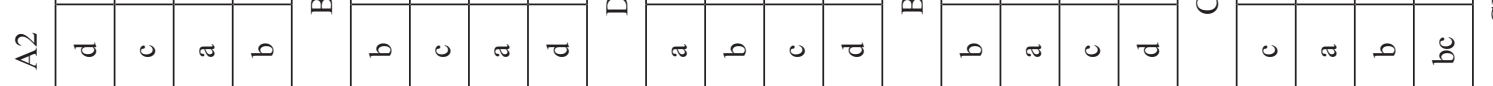
ֻٕ:

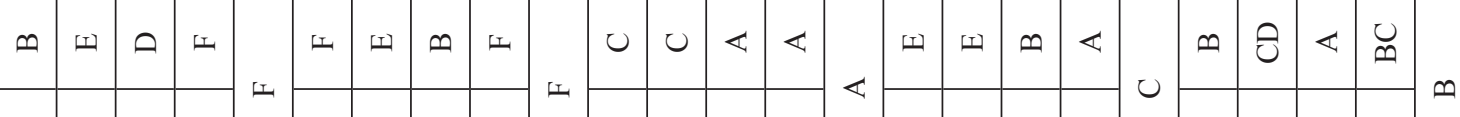

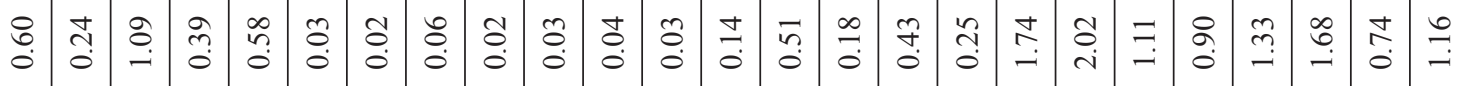
离

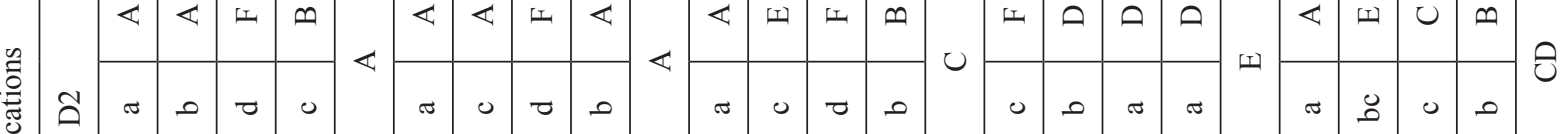
$\stackrel{8}{\bullet}$

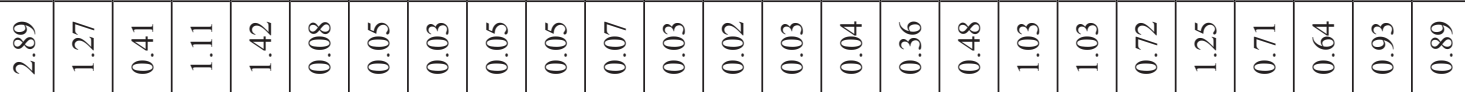

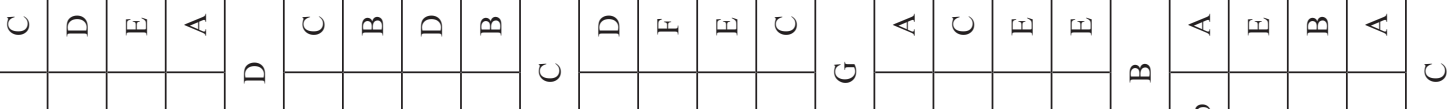

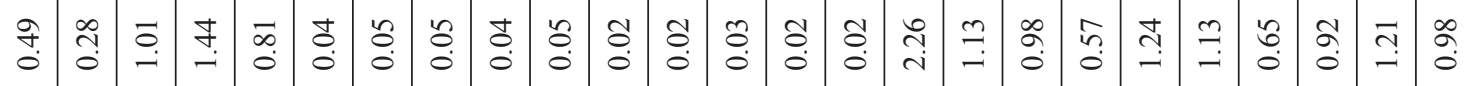
د

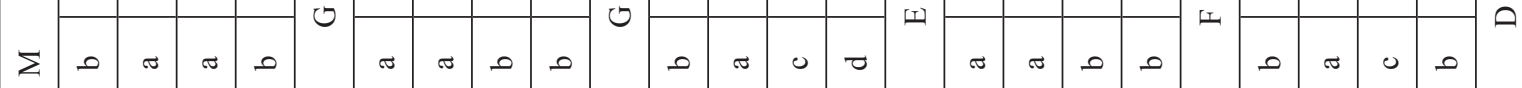
m 山

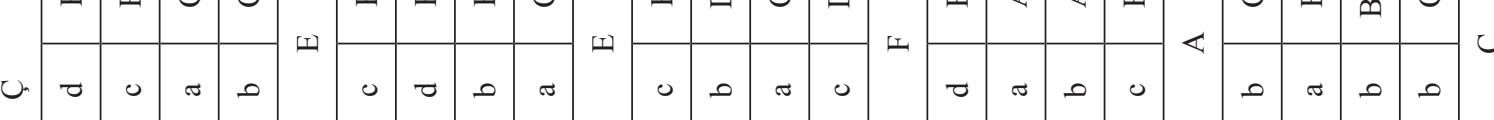
ڤే

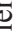
蒫 ڤั: 完

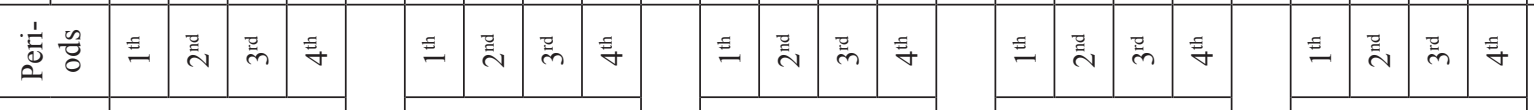




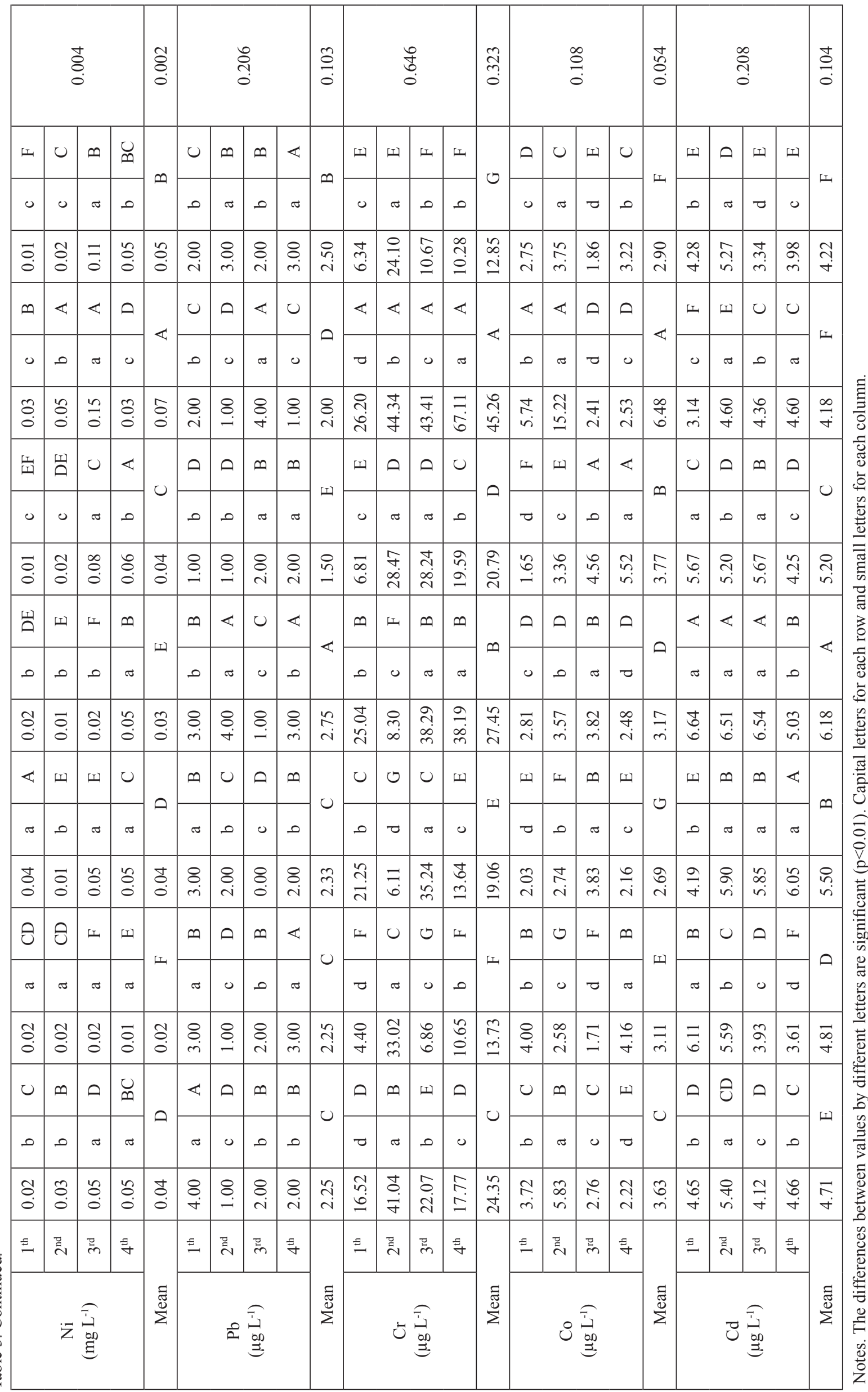


industrial wastewaters [16, 23-24]. High $\mathrm{pH}$ values affect not only biodiversity in the water but also the solubility and accumulation of some elements in soils that are irrigated with these waters [23].

Water samples taken at summer period had the highest concentration of $\mathrm{Pb}\left(2.57 \mu \mathrm{g} \mathrm{L}^{-1}\right)$ among all the other sampling periods; however, the value was found to be under the limitations of WHO, FAO and TW. In the autumn period concentrations of $\mathrm{Al}$ $\left(2.42 \mathrm{mg} \mathrm{L}^{-1}\right) \mathrm{Cr}\left(26.48 \mu \mathrm{g} \mathrm{L}^{-1}\right)$, Co $\left(5.29 \mu \mathrm{g} \mathrm{L}^{-1}\right)$ and $\mathrm{Cd}$ $\left(5.50 \mu \mathrm{g} \mathrm{L}^{-1}\right)$ were found to be highest of all the other sampling periods. Their amounts were found to be below the limitations, except for $\mathrm{Cd}$ and $\mathrm{Cr}$. $\mathrm{Cd}$ amount was over the limit of WHO and $\mathrm{Cr}$ was over the limit of TW. In the winter period the amounts of $\mathrm{Cr}\left(26.40 \mu \mathrm{g} \mathrm{L}^{-1}\right)$, Fe (1.42 $\left.\mathrm{m} \mathrm{L} \mathrm{L}^{-1}\right), \mathrm{Cu}\left(0.05 \mathrm{mg} \mathrm{L}^{-1}\right), \mathrm{Mn}\left(1.08 \mathrm{mg} \mathrm{L}^{-1}\right)$ and $\mathrm{Ni}\left(0.07 \mathrm{mg} \mathrm{L}^{-1}\right)$ were found to be higher when compared to other periods. Among these elements, $\mathrm{Fe}, \mathrm{Zn}$ and $\mathrm{Mn}$ are used as fertilizer in agricultural areas, and $\mathrm{Cu}$ is used as Bordeaux mixture (a fungicidal mixture). High concentrations of these elements in winter were thought to have occurred because of leaching from soil via precipitation. Similar to our findings, the highest $\mathrm{Cd}, \mathrm{Pb}, \mathrm{Ni}, \mathrm{Cu}, \mathrm{Zn}, \mathrm{Mn}$, and $\mathrm{Fe}$ results were reported in winter from the research of Abdel Satar et al. [1]. The findings of Khan et al. [25] also support our findings, especially the iron levels that were found to be higher in winter than in summer. Mn amount was high according to the limits of WHO, FAO and TW. Although $\mathrm{Fe}, \mathrm{Cu}, \mathrm{Ni}$ and $\mathrm{Cr}$ amounts were over the limitations of TW, Fe was also found to be high accordingto the limits of WHO, but below the limits of FAO. $\mathrm{Zn}\left(0.09 \mathrm{mg} \mathrm{L}^{-1}\right)$ amount rose to the maximum in the spring; but the amount was found to be under the limits. Patel et al. [23] reported the declining trend of
Mn due to the indiscriminate discharge from smelting industries and urban and temple wastes. Parallel to our research results, Saha et al. [6] reported higher $\mathrm{Cu}$ and $\mathrm{Zn}$ results in the Dhaka Export Processing Zone and attributed this to the cumulative impact of numerous industries and also extensive use of fertilizers, and $\mathrm{Cu}-\mathrm{Zn}$ based pesticides in the agricultural lands $[6$, $11,23]$.

Waters taken from the Nilüfer tributaries have interchangeable trace element and heavy metal contents. The values obtained from the analysis results varied according to the sources and sampling periods $(\mathrm{p}<0.01)$ (Table 3). Mn concentrations of the waters taken from the tributaries of the stream were found to be over the limits of WHO, FAO and TW. In contrast, $\mathrm{Pb}$ concentration of the water samples was found to be under the limits of WHO, FAO and TW. Neither of the samples taken from the tributaries have higher $\mathrm{Al}$, nor does $\mathrm{Co}$ amount to more than the indicated limits. Most of the water samples' $\mathrm{Cu}, \mathrm{Zn}, \mathrm{Ni}$ and $\mathrm{Cr}$ concentrations were also found to be below the limits; however, $\mathrm{Cu}$ contents of the waters taken from Deliçay 1 (D1) and Deliçay 2 (D2); $\mathrm{Zn}$ content of the water taken from Ayvalı 1 (A1); $\mathrm{Ni}$ content of the water taken from Ayval1 2 (A2) and $\mathrm{Cr}$ amounts taken from Çayönü (Ç), D2, A1 and A2 were found to be over the limits of TW. Although Al, $\mathrm{Fe}$ and $\mathrm{Cd}$ concentrations of the samples were found to be under the limits of FAO, Cd amounts according to $\mathrm{WHO}$ and $\mathrm{Fe}$ amounts according to $\mathrm{WHO}$ and TW were found to be over the limits. Although being under the limits of FAO makes the waters of Nilüfer Stream usable for irrigation, being over the limits of WHO and TW restricts it for drinking. Water pollution was common when the streams, canals and lakes passed through cities or populated areas and were contaminated

Table 4. Seasonal variations of the trace element and heavy metal concentrations of the waters taken from treatment plants.

\begin{tabular}{|c|c|c|c|c|c|c|c|c|c|c|c|c|}
\hline \multirow{3}{*}{$\begin{array}{c}\mathrm{WHO}^{*} \\
0.3\end{array}$} & \multirow{3}{*}{$\begin{array}{c}\mathrm{FAO}^{* *} \\
5.0\end{array}$} & \multirow{3}{*}{$\begin{array}{c}\mathrm{TW}^{* * * *} \\
0.33\end{array}$} & \multirow{3}{*}{$\begin{array}{l}\text { Parameters } \\
\mathrm{Fe}\left(\mathrm{mg} \mathrm{L}^{-1}\right)\end{array}$} & \multicolumn{8}{|c|}{ Periods } & \multirow{3}{*}{$\begin{array}{c}\begin{array}{c}\text { LSD } \\
(\mathrm{p}<0.01)\end{array} \\
0.013\end{array}$} \\
\hline & & & & \multicolumn{2}{|c|}{$\begin{array}{c}1^{\text {th }} \\
\text { (Summer) }\end{array}$} & \multicolumn{2}{|c|}{$\begin{array}{c}2^{\text {nd }} \\
\text { (Autumn) }\end{array}$} & \multicolumn{2}{|c|}{$\begin{array}{c}3^{\text {rd }} \\
\text { (Winter) }\end{array}$} & \multicolumn{2}{|c|}{$\begin{array}{c}4^{\text {th }} \\
\text { (Spring) }\end{array}$} & \\
\hline & & & & 0.39 & $\mathrm{C}$ & 0.37 & D & 1.69 & A & 0.78 & B & \\
\hline 2.0 & 0.2 & 0.03 & $\mathrm{Cu}\left(\mathrm{mg} \mathrm{L}^{-1}\right)$ & 0.032 & $\mathrm{C}$ & 0.022 & D & 0.071 & A & 0.050 & B & 0.001 \\
\hline 3.0 & 2.0 & 0.12 & $\mathrm{Zn}\left(\mathrm{mg} \mathrm{L}^{-1}\right)$ & 0.04 & $\mathrm{C}$ & 0.04 & D & 0.06 & A & 0.05 & B & 0.0001 \\
\hline 0.5 & 0.2 & 0.05 & $\operatorname{Mn}\left(m g L^{-1}\right)$ & 0.55 & A & 0.48 & B & 0.45 & $\mathrm{C}$ & 0.47 & B & 0.013 \\
\hline- & 5.0 & - & $\mathrm{Al}\left(\mathrm{mg} \mathrm{L}^{-1}\right)$ & 0.87 & B & 0.95 & A & 0.64 & $\mathrm{C}$ & 0.95 & A & 0.01 \\
\hline- & 0.2 & 0.06 & $\mathrm{Ni}\left(\mathrm{mg} \mathrm{L}^{-1}\right)$ & 0.02 & $\mathrm{C}$ & 0.02 & $\mathrm{C}$ & 0.07 & A & 0.05 & B & 0.007 \\
\hline 10 & 2000 & 190 & $\mathrm{~Pb}\left(\mu \mathrm{g} \mathrm{L}^{-1}\right)$ & 2.40 & B & 2.00 & $\mathrm{C}$ & 1.80 & $\mathrm{D}$ & 3.60 & A & 0.130 \\
\hline 50 & 100 & 20 & $\mathrm{Cr}\left(\mu \mathrm{g} \mathrm{L}^{-1}\right)$ & 16.49 & $\mathrm{C}$ & 19.29 & B & 16.16 & $\mathrm{D}$ & 23.89 & A & 0.243 \\
\hline- & 50 & 50 & $\mathrm{Co}\left(\mu \mathrm{g} \mathrm{L}^{-1}\right)$ & 2.06 & $\mathrm{C}$ & 3.10 & B & 3.20 & B & 3.94 & A & 0.209 \\
\hline 3 & 10 & - & $\mathrm{Cd}\left(\mu \mathrm{g} \mathrm{L}^{-1}\right)$ & 4.48 & B & 5.14 & A & 4.41 & B & 3.98 & C & 0.088 \\
\hline
\end{tabular}

Notes. The differences between values by different capital letters are significant $(p<0.01)$.

"Max: permissible limit for drinking purpose/human consumption (17)

${ }^{* *}$ Recommended maximum concentration for irrigation/crop production (18)

${ }^{* * *}$ Average quality characteristics of Treated Wastewaters (TW) used for irrigation (19) 
by substances harmful to living things. Pollution makes streams, channels and lake waters discontent in terms of appearance, smell and swimming. People who drink dirty water and who have been exposed to dirty water for a long time may get sick, develop cancer, or have birth defects [3-6, 24, 26-30].

With respect to the mean results of the water samples taken periodically from the tributaries of the stream, higher amounts of $\mathrm{Fe}, \mathrm{Mn}, \mathrm{Cr}$ and $\mathrm{Cd}$ were determined at the water samples taken from $\mathrm{C}$ sampling point. Sampling point Misi (M) was found to be the least contaminated sampling point of the stream where there is no wastewater and industrial discharge. However, $\mathrm{Mn}$ and $\mathrm{Cd}$ amounts were not only the elements which pollute Misi but they also were detected over the limits at all of the other sampling points. This situation was found to be related to the mining, dam and road construction activities and also was found to be related to the fertilizers used in agricultural activities. Sönmez et al. (31) reported that the use of phosphoric acid increases the $\mathrm{Cd}, \mathrm{Pb}, \mathrm{Ni}$ and $\mathrm{As}$ concentrations in the soil. Iron $(\mathrm{Fe})$ is the third mostly found element, which was over the limits according to WHO and TW at all of the sampling points except sampling point $\mathrm{M}$. High $\mathrm{Fe}, \mathrm{Cu}, \mathrm{Mn}$, and $\mathrm{Cd}$ amounts were determined at D1, D2 and Hasanağa $(\mathrm{H})$ sampling points. These points are very close to the agricultural lands and the high amounts of the elements were found to be related to the fertilizer and pesticide usage at the agricultural activities. High consumption of pesticides containing high amounts of $\mathrm{Cu}$ increase their concentrations in the soil, plants and also in the water [31-32]. A1 and A2 sampling points also suffer from high amounts of Fe, $\mathrm{Mn}$ and $\mathrm{Cd}$. In contrast to the other sampling points, $\mathrm{Zn}$ amount of $\mathrm{A} 1$ and $\mathrm{Ni}$ amount of $\mathrm{A} 2$ were found to be over the limits. High amounts of these elements were found to be related to agricultural and industrial activities. $\mathrm{Al}, \mathrm{Pb}$ and $\mathrm{Co}$ concentrations of the water samples taken from the tributaries of the stream were determined to be below the limits. They were also found to be below the limits at the samples taken from the treatment plants. Anthropogenic emission of the heavy metals in both organic and inorganic forms have been reported as the sources of various industrial spots such as old and present mining sites, foundries and smelting wastes, combustion by-products and traffic [23]. Through rivers and streams, metals are transported as dissolved in water or as suspended particles and stored in river beds or underground waters. Karaca and Tasdemir [14] also reported pollution in Nilüfer Stream due to the illegally discharged industrial wastewater, municipal sewage discharges, solid waste disposals in stream beds, drainage water, erosion and atmospheric pollutants. Contamination of surface and groundwater resources with heavy metals leads to soil pollution, causes accumulation in plants grown on it and affects negatively all living things, including animals and humans that are fed with these plants $[2,8,23]$. Plant nutrients that are poorly soluble in the soil lead to deficiencies in the plant, and in contrast high soluble may lead accumulation and pollution in the soil [12, 23]. Aydinalp et al. [33] also reported heavy metal accumulation in the surface horizons of agricultural soils irrigated by the Nilüfer over a long-term period.

Seasonal variations of the trace element and heavy metal concentrations of the water samples taken from the wastewater treatment plants are shown in Table 4. Among the trace elements and heavy metals, $\mathrm{Zn}, \mathrm{Pb}$, $\mathrm{Co}$ and $\mathrm{Al}$ concentrations of the waters taken from treatment plants were found to be under the limits of WHO, FAO and TW throughout all periods. However, according to WHO safe limits, concentrations of Fe, $\mathrm{Mn}$, and $\mathrm{Cd}$ according to FAO Mn concentrations and according to treated water limitations, $\mathrm{Fe}, \mathrm{Cu}, \mathrm{Mn}$, and $\mathrm{Cr}$ values of the waters were found to be high in one or more of the sampling periods (Table 4).

Trace element and heavy metal concentrations of the waters taken from the treatment plants also differ depending on the sampling periods $(p<0.01)$. Concentrations were found to be higher at tributaries when compared to the amounts in treatment plants. Water samples taken in the summer period had the highest $\mathrm{Mn}$ (0.55 $\left.\mathrm{mg} \mathrm{L}^{-1}\right)$ among all the sampling periods, and the concentration was found to be over the limits of WHO, FAO and TW. In the autumn period, $\mathrm{Cd}$ $\left(5.14 \mu \mathrm{g} \mathrm{L}^{-1}\right)$ and $\mathrm{Al}\left(0.95 \mathrm{mg} \mathrm{L}^{-1}\right)$ amounts were found to be the highest. Although the amounts were under the limits of FAO, Cd was found to be over the limits of WHO. In the winter period, values of Fe $\left(1.69 \mathrm{mg} \mathrm{L}^{-1}\right)$, $\mathrm{Cu}\left(0.071 \mathrm{mg} \mathrm{L}^{-1}\right), \mathrm{Zn}\left(0.06 \mathrm{mg} \mathrm{L}^{-1}\right)$ and $\mathrm{Ni}\left(0.07 \mathrm{mg} \mathrm{L}^{-1}\right)$ were found to be the highest. Although the amounts of $\mathrm{Zn}$ were below the limits of WHO, FAO and TW, Fe was found to be high according to the limits of WHO and TW. In accordance with the limits of TW, $\mathrm{Cu}$ was also found to be over the limits. In the spring period, besides the Al concentration $\left(0.95 \mathrm{mg} \mathrm{L}^{-1}\right), \mathrm{Pb}$ (3.60 $\left.\mu \mathrm{g} \mathrm{L}^{-1}\right), \mathrm{Cr}\left(23.89 \mu \mathrm{g} \mathrm{L}^{-1}\right)$ and Co $\left(3.94 \mu \mathrm{g} \mathrm{L}^{-1}\right)$ also reached the highest levels. $\mathrm{Pb}$ and $\mathrm{Co}$ concentrations of the waters were found to be under the limits of WHO, FAO and TW. Cr was also below the limits of WHO and FAO, but its amount was found to be over the limits of TW. Seasonal differences between the concentrations of the elements were found to be related with the processed products at the factories and also their discharge from treatment plants. The textile industry uses paint and some chemicals, including heavy metals, the food industry uses salt and also various chemicals and they reproduce different products at different time periods. These products release different wastes and change the waters' composition. Waters taken from the treatment plants also have interchangeable trace element and heavy metal contents. The values obtained from the analysis results differ according to the sources from which the samples were taken, and also change according to the sampling periods $(\mathrm{p}<0.01)$ (Table 5). $\mathrm{Zn}, \mathrm{Al}, \mathrm{Ni}, \mathrm{Pb}$, and Co concentrations of the water samples taken from the treatment plants were found to be under the limits of WHO, FAO and TW. In contrast, Mn amounts of 


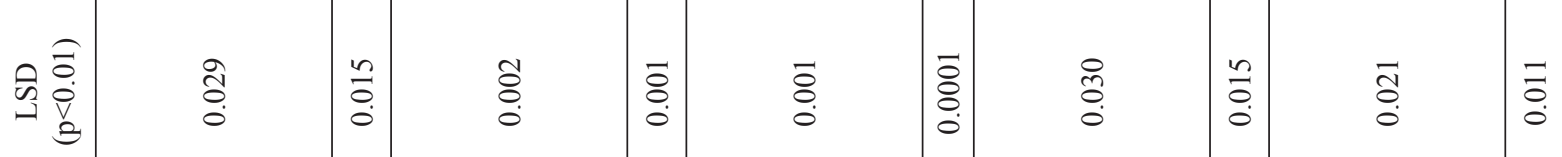

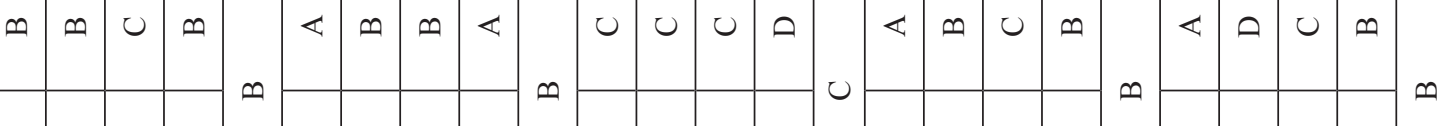

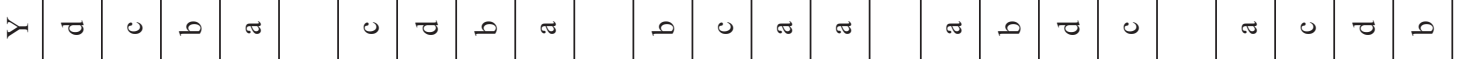

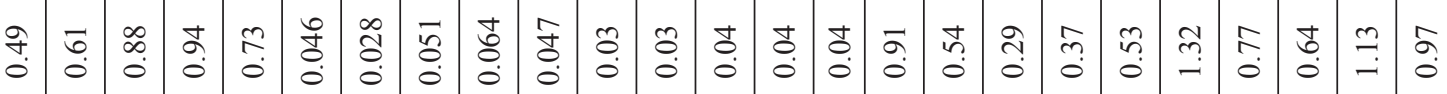
○ ค 监 范

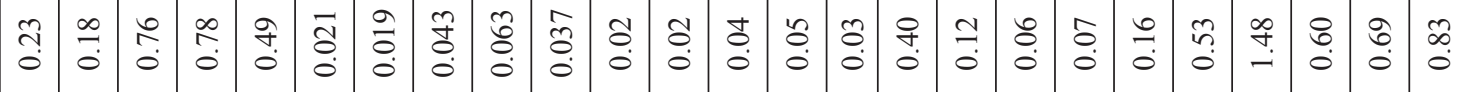




\begin{tabular}{|c|c|c|c|c|c|c|c|c|c|c|c|c|c|c|c|c|c|c|c|c|c|c|c|c|}
\hline \multicolumn{4}{|c|}{$\stackrel{0}{\circ}$} & $\begin{array}{l}\infty \\
\stackrel{0}{0} \\
\stackrel{0}{0}\end{array}$ & \multicolumn{4}{|c|}{$\begin{array}{l}\text { సे } \\
\text { (2) }\end{array}$} & & \multicolumn{4}{|c|}{ ?̊ } & 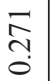 & \multicolumn{4}{|c|}{$\begin{array}{l}\infty \\
\vdots \\
0 \\
0\end{array}$} & ָั & & \\
\hline$\varangle$ & 学 & $u$ & $\varangle$ & & U & U & $\varangle$ & U & & $\varangle$ & $\varangle$ & $\varangle$ & $\varangle$ & & $\varangle$ & $\stackrel{q}{2}$ & 8 & $\infty$ & & 디 & D & $m$ & & \\
\hline مـ & مـ & $\sigma$ & $\pi$ & & م & 0 & م & $\sigma$ & & م & $\tau$ & 0 & $\pi$ & & مـ & مـ & 0 & $\pi$ & & مـ & مـ & $\approx$ & مـ & \\
\hline$\stackrel{d}{\sigma}$ & $\stackrel{0}{\circ}$ & $\begin{array}{l} \pm \\
0 \\
0\end{array}$ & $\stackrel{\text { on }}{\circ}$ & ô. & $\underset{i}{\stackrel{i}{ }}$ & $\underset{-}{8}$ & $\underset{i}{8}$ & $\underset{\dot{m}}{\stackrel{8}{ }}$ & & $\begin{array}{l}n \\
n \\
\text { of }\end{array}$ & $\stackrel{\infty}{\stackrel{\infty}{\sim}}$ & 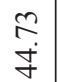 & $\frac{n}{n} \cdot \frac{1}{n}$ & $\begin{array}{l}n \\
\dot{y} \\
\dot{f}\end{array}$ & in & $\underset{r}{g}$ & $\begin{array}{l}\stackrel{\overbrace{}}{n} \\
i\end{array}$ & $\underset{+}{\vec{f}}$ & nे & $\overrightarrow{\bar{m}}$ & m্ & $\begin{array}{l}\text { So } \\
\dot{f}\end{array}$ & 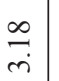 & $\begin{array}{l}n \\
n \\
n\end{array}$ \\
\hline$\varangle$ & $\stackrel{m}{<}$ & $ص$ & 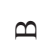 & & D & 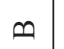 & $\varangle$ & 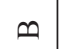 & & U & 피 & D & D & & U & 学 & D & $U$ & & D & 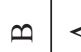 & $\varangle$ & $\varangle$ & \\
\hline مـ & م & $\pi$ & م & & $\tau$ & مـ & 0 & $\pi$ & & مـ & 0 & 0 & $\pi$ & & 0 & $\pi$ & مـ & $\pi$ & & $\tau$ & $\pi$ & م & 0 & \\
\hline $\begin{array}{l}\widetilde{0} \\
\text { o. }\end{array}$ & $\stackrel{\text { ô }}{0}$ & $\stackrel{0}{0}$ & $\stackrel{\leftrightarrow}{\circ}$ & ô. & $\stackrel{8}{-}$ & $\underset{\dot{m}}{\stackrel{m}{2}}$ & $\underset{i}{\stackrel{8}{i}}$ & $\underset{+}{\stackrel{8}{+}}$ & $\frac{\text { of }}{0}$ & $\stackrel{\vec{J}}{\Xi}$ & $\overbrace{\infty}^{\infty}$ & के. & $\begin{array}{c}m \\
m \\
m\end{array}$ & $\begin{array}{l}\stackrel{+}{\sim} \\
\stackrel{0}{0}\end{array}$ & $\stackrel{n}{0}$ & $\stackrel{\vec{m}}{\vec{m}}$ & 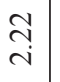 & $\stackrel{f}{\dot{r}}$ & ঙ্ণি & 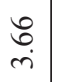 & $\begin{array}{l}\infty \\
\dot{\sim} \\
\text { in }\end{array}$ & : & $\begin{array}{l}\stackrel{0}{+} \\
+\end{array}$ & $\begin{array}{l}\text { bे } \\
+\end{array}$ \\
\hline$\varangle$ & $\varangle$ & $\stackrel{q}{<}$ & $\varangle$ & & 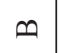 & $\varangle$ & $\infty$ & u & D & $m$ & 0 & 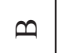 & $u$ & & 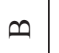 & $\varangle$ & $\varangle$ & $\varangle$ & . & $\infty$ & U & u & 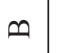 & \\
\hline م & م & $\sigma$ & $\sigma$ & & مـ & $\sigma$ & 0 & م & $\begin{array}{l}\underset{0}{0} \\
\text { i }\end{array}$ & $\sigma$ & 0 & 0 & مـ & & $\tau$ & 0 & م & $\sigma$ & & $\sigma$ & م & o & $\sigma$ & \\
\hline $\begin{array}{l}\sigma \\
\stackrel{0}{0}\end{array}$ & $\stackrel{\overbrace{}}{0}$ & $\stackrel{0}{0}$ & $\stackrel{\circ}{\circ}$ & $\begin{array}{l}\text { J } \\
0\end{array}$ & $\underset{\dot{r}}{\stackrel{.}{1}}$ & $\begin{array}{l}8 \\
+ \\
+\end{array}$ & $\underset{-}{\stackrel{8}{2}}$ & $\underset{r}{\stackrel{8}{ }}$ & U & బֶ. & 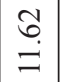 & 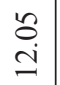 & 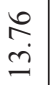 & $\begin{array}{l}\stackrel{n}{m} \\
\stackrel{\sim}{7}\end{array}$ & $\stackrel{?}{\longrightarrow}$ & $\stackrel{\vartheta}{i}$ & $\underset{+}{\stackrel{?}{+}}$ & $\begin{array}{l}\stackrel{\infty}{n} \\
\stackrel{n}{n}\end{array}$ & $\tilde{\sigma}$ & $\frac{\infty}{n}$ & $\stackrel{\infty}{\sim}$ & ते & $\begin{array}{l}\stackrel{\infty}{\stackrel{\rho}{r}} \\
\dot{r}\end{array}$ & $\stackrel{m}{\stackrel{m}{+}}$ \\
\hline$\varangle$ & $\infty$ & $\frac{m}{4}$ & $\varangle$ & & D & U & $\varangle$ & U & $\begin{array}{l}\stackrel{n}{n} \\
\text { ris }\end{array}$ & 피 & 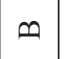 & 피 & 띠 & & 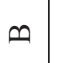 & 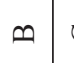 & 0 & $\infty$ & . & 0 & 0 & ค & $\ll$ & \\
\hline مـ & مـ & $\pi$ & $\pi$ & & 0 & 0 & م & $\pi$ & $m$ & $\tau$ & $\pi$ & 0 & مـ & & 0 & مـ & مـ & $\pi$ & & $\pi$ & $\pi$ & م & $\pi$ & \\
\hline$\stackrel{\overrightarrow{0}}{0}$ & $\stackrel{0}{\circ}$ & $\stackrel{n}{\circ}$ & $\stackrel{n}{0}$ & $\stackrel{\text { ô }}{0}$ & $\stackrel{8}{\longrightarrow}$ & $\stackrel{8}{\longrightarrow}$ & 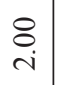 & $\underset{r}{\stackrel{8}{ }}$ & $\stackrel{n}{\stackrel{n}{i}}$ & $\stackrel{\stackrel{7}{\sim}}{\sim}$ & $\begin{array}{l}\infty \\
\infty \\
u \\
\sim\end{array}$ & $\frac{n}{6}$ & $\begin{array}{l}\stackrel{\infty}{0} \\
\stackrel{0}{0}\end{array}$ & $\stackrel{\text { nִ }}{=}$ & $\stackrel{f}{\text { f }}$ & $\frac{\partial}{m}$ & $\underset{\infty}{\infty}$ & $\stackrel{n}{n}$ & $\underset{\sim}{\tilde{r}}$ & $\underset{+}{\vec{f}}$ & $\begin{array}{l}\vec{\leftarrow} \\
\dot{+}\end{array}$ & $\begin{array}{l}\infty \\
\text { ले }\end{array}$ & $\stackrel{n}{n}$ & $\stackrel{\mathscr{P}}{+}$ \\
\hline$\varangle$ & $\stackrel{q}{z}$ & $\varangle$ & $\varangle$ & & $\varangle$ & U & $\varangle$ & $\varangle$ & 山 & 0 & U & U & 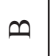 & & $\varangle$ & U & $\infty$ & A & & $\varangle$ & $\varangle$ & U & $\varangle$ & \\
\hline 0 & 0 & $\sigma$ & م & & $\sigma$ & 0 & م & $\sigma$ & $\stackrel{n}{I}$ & $\tau$ & م & 0 & $\sigma$ & & $\sigma$ & م & $\sigma$ & م & & م & $\sigma$ & $\nabla$ & 0 & \\
\hline$\tilde{o}_{0}$ & $\stackrel{0}{0}$ & $\stackrel{7}{0}$ & $\stackrel{\text { on }}{0}$ & : & $\begin{array}{l}8 \\
\text { in }\end{array}$ & $\stackrel{8}{-}$ & $\underset{i}{\stackrel{8}{~}}$ & $\underset{r}{8}$ & $\varangle$ & $\underset{f}{\stackrel{g}{f}}$ & $\begin{array}{l}\bar{Z} \\
\vec{\lambda}\end{array}$ & $\stackrel{\infty}{\stackrel{\infty}{\sigma}}$ & $\frac{ \pm}{\dot{D}}$ & $\begin{array}{l}\vec{\infty} \\
\stackrel{0}{0}\end{array}$ & $\stackrel{n}{n}$ & $\stackrel{?}{i}$ & $\stackrel{\substack{n \\
m}}{m}$ & $\stackrel{\text { fo }}{-}$ & $\begin{array}{l}\stackrel{\overbrace{}}{\sim} \\
i\end{array}$ & $\begin{array}{l}\stackrel{n}{n} \\
i\end{array}$ & $\stackrel{?}{?}$ & 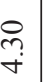 & $\begin{array}{l}\underset{+}{+} \\
\stackrel{+}{*}\end{array}$ & 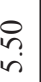 \\
\hline$\equiv$ & $\stackrel{\Xi}{\sim}$ & 总 & $\xi$ & & $\Xi$ & 总 & $\stackrel{\Xi}{m}$ & F & $\stackrel{n}{n}$ & $\equiv$ & 䓂 & $\stackrel{\square}{m}$ & $\bar{F}$ & & $\Xi$ & 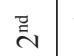 & $\stackrel{\Xi}{m}$ & F & & $\equiv$ & $\ddot{\beth}$ & $\ddot{m}$ & F & \\
\hline & & 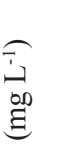 & & $\sum_{\Sigma}^{\bar{\varpi}}$ & & 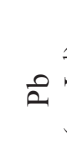 & (ב) & & $\sum_{\Sigma}^{\frac{5}{\Sigma}}$ & & 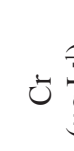 & 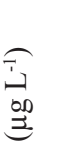 & & $\sum_{\Sigma}^{\bar{\Xi}}$ & & & & & 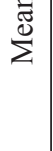 & & $\tilde{U}$ & & & $\stackrel{\bar{\varpi}}{\bar{\Sigma}}^{\circ}$ \\
\hline
\end{tabular}


the waters were higher than the indicated limits. $\mathrm{Cu}$ concentrations of the waters taken from the treatment plants except Buski West (BW) were found to be high according to the limits of TW $\left(>0.03 \mathrm{mg} \mathrm{L}^{-1}\right)$. Although $\mathrm{Fe}$ concentrations of the waters taken from the treatment plants were found to be under the limits of FAO, their amounts were found to be over the limits of WHO and TW. Cd concentrations of the water samples taken from the treatment plants were low according to the limits of FAO, however they were high when compared to the limits of WHO. Although $\mathrm{Cr}$ amounts of the samples were below the limits, water sample taken from Yeşil (Y) had high $\mathrm{Cr}$ concentrations according to the TW limits.

The mean results of the water samples taken periodically from the treatment plants showed higher amounts of $\mathrm{Fe}$, and $\mathrm{Cd}$ at whole of the water samples. $\mathrm{Cu}$ and $\mathrm{Mn}$ amounts of the waters were also high except for the sampling point Buski West (BW) for $\mathrm{Cu}$ and except for the sampling point Penguen (P) for Mn. Among to the treatment plants, Sütaş (S) has lots of contaminants of higher $\mathrm{Fe}, \mathrm{Cu}, \mathrm{Zn}, \mathrm{Mn}, \mathrm{Al}, \mathrm{Ni}, \mathrm{Pb}$ and $\mathrm{Cd}$ amounts. Yeşil (Y) was also observed as an important treatment plant because of its discharges containing high amounts of $\mathrm{Fe}, \mathrm{Cu}, \mathrm{Mn}, \mathrm{Cr}$, and $\mathrm{Cd}$. Buski East (BE) is an important treatment plant of municipal wastes and was the least contaminating among the other treatment plants. Some heavy metals have been reported as bio important elements to humans, like Fe and $\mathrm{Zn}$. However, others have been reported as toxic [3, 6, 8, 24, 26, 34]. $\mathrm{Zn}, \mathrm{Al}, \mathrm{Ni}, \mathrm{Pb}$, and $\mathrm{Co}$ concentrations of the water samples taken from the treatment plants were found to be under the limits of WHO, FAO and TW. Related to the discharged concentrations to the stream $\mathrm{Zn}, \mathrm{Al}$, $\mathrm{Pb}$, and $\mathrm{Co}$, concentrations of the tributaries were also under the limits of WHO, FAO and TW throughout all seasons. However, concentrations of especially $\mathrm{Mn}, \mathrm{Fe}$, $\mathrm{Cu}, \mathrm{Cd}$ and $\mathrm{Cr}$ were high at treatment plants and also high in the water samples taken from the tributaries. Sampling point $\mathrm{M}$ is the place where there is no wastewater and industrial discharge at Nilüfer Stream and was indicated as the least-polluted sampling point. These results taken from our research also confirm that the treatment plants induced contamination. Parallel to the findings of our results, Aydinalp et al. [33] also reported the pollution in Nilüfer Stream as a result of industrial wastewater and sewage effluents. Üstün [16] investigated the change of heavy metals according to time intervals in Nilüfer Stream and determined that the water quality of the stream worsened within a year. Especially dense wastewater discharge formed a dirty flow and was classified as "highly contaminated water" in terms of $\mathrm{Cr}$ and $\mathrm{Pb}$ levels at the exit point of Nilüfer Stream according to the National Surface Water Quality Classification [16].

Heavy metal accumulation was recorded at sampling points, which varied considerably during periods and locations. The change in heavy metal concentration has been attributed to the use of different raw materials and the variation in production level, as noted in previous studies [7, 23].

Discharge of domestic and industrial wastewater to the stream without treatment may cause deterioration in water quality over time and the use of water for many years in agricultural activities leads to problems as a result of pollution of the agricultural areas due to the heavy metals in the water [14, 23]. The high $\mathrm{Cu}$ concentration in the water has been reported as a pollution index from the wastes in the channels or water bodies [23-24]. Although copper is not a cumulative systemic poison, overdose usually affects not only soil but also water, and copper in high amounts $(>1.0 \mathrm{mg})$ is harmful and causes central nervous system impairment, hair pigmentation failure, Fe metabolism, gastric and intestinal distress, kidney damage and anemia [8, 24]. It has been reported that consumption of long-term drinking water containing iron at high concentrations can lead to liver diseases, gastro intestinal bleeding, vomiting and diarrhea [26-27]. It has also been reported that toxic metals, in particular various pollutants containing $\mathrm{Cu}$ and $\mathrm{Zn}$, are found everywhere in rivers, in reservoirs, and are disadvantageous for aquatic organisms [23-24]. The accumulation of these elements in soils and in crops may be dangerous to humans and animals. For this reason, it is necessary to constantly monitor the toxic element concentrations in the soil and plants or to treat the sewage water before it is used for irrigation [28, 35-37].

\section{Conclusions}

Results of this work reveal that the quality of Nilüfer Stream has fallen because of pollution due to industrial and unconscious agricultural activities. For this reason, attention should be paid to household consumption, and irrigation and industrial uses. In addition, it is important to recheck and develop the treatment processes of the treatment plants because of their high contaminant element concentration according to the treated water limitations. In addition, industrial and urban wastewater treatment plants discharging criteria must be rearranged and should be closely monitored by the local authorities.

\section{Acknowledgements}

This manuscript was prepared with some components of a M.Sc. thesis. The authors thank Sita Sanele KUNENE for his contribution regarding the English grammar of our manuscript.

\section{Conflict of Interest}

The authors declare no conflict of interest. 


\section{References}

1. ABDEL-SATAR A.M., ALI M.H., GOHER M.E. Indices of water quality and metal pollution of Nile River, Egypt. The Egyptian Journal of Aquatic Research, 43 (1), 1, 2017.

2. KARACAOĞLU D., DALKIRAN N. Epilithic diatom assemblages and their relationships with environmental variables in the Nilüfer Stream Basin, Bursa, Turkey. Environmental monitoring and assessment, 189 (5), 227, 2017.

3. ESPÍN S., MARTÍNEZ-LÓPEZ E., JIMÉNEZ P., MARÍA-MOJICA P., GARCÍA-FERNÁNDEZ A.J. Effects of heavy metals on biomarkers for oxidative stress in Griffon vulture (Gyps fulvus). Environmental research, 129, 59, 2014.

4. ARMENDÁRIZ C.R., GARCIA T., SOLER A., FERNÁNDEZ Á.J.G., GLEZ-WELLER D., GONZÁLEZ G.L., DE LA TORRE A.H., GIRONÉS C.R. Heavy metals in cigarettes for sale in Spain. Environmental research, 143, 162, 2015.

5. SAHA N., RAHMAN M.S., JOLLY Y.N., RAHMAN A., SATTAR M.A., HAI M.A., Spatial distribution and contamination assessment of six heavy metals in soils and their transfer into mature tobacco plants in Kushtia District, Bangladesh. Environmental Science and Pollution Research, 23 (4), 3414, 2016.

6. SAHA N., RAHMAN M.S., AHMED M.B., ZHOU J.L., NGO H.H., GUO W. Industrial metal pollution in water and probabilistic assessment of human health risk. Journal of environmental management, 185, 70, 2017.

7. CENGIZ M.F., KILIC S., YALCIN F., KILIC M., YALCIN M.G. Evaluation of heavy metal risk potential in Bogacayi River water (Antalya, Turkey). Environmental monitoring and assessment, 189 (6), 248, 2017.

8. IDOKO J.O., WUANA R.A., MUSA W.O. Assessment of Heavy Metal Levels in Juji River Water and Catchment Soil in Kaduna City, Nigeria. Journal of Chemical Society of Nigeria, 41 (1), 2016.

9. BREŚ W., KLEIBER T., TRELKA T. Quality of water used for drip irrigation and fertigation of horticultural plants. Folia Horticulturae 22 (2), 67, 2010.

10. ASHRAF M.A., MAAH M.J., YUSOFF I. Water quality characterization of varsity lake, University of Malaya, Kuala Lumpur, Malaysia. Journal of Chemistry, 7 (1), 245, 2010.

11. ALVES R.I., SAMPAIO C.F., NADAL M., SCHUHMACHER M., DOMINGO J.L., SEGURAMUÑOZ S.I. Metal concentrations in surface water and sediments from Pardo River, Brazil: human health risks. Environmental research, 133, 149, 2014.

12. DORAK S., ÇELIK, H. Irrigation water quality of nilufer stream and effects of the wastewater discharges of the treatment plants. Ege Üniversitesi Ziraat Fakültesi Dergisi, 54 (3), 249, 2017.

13. ÜSTÜN G.E., KARAER F., SOLMAZ S.K.A. Bursa Nilüfer çayının sulama suyu olarak kullanılabilirliğinin değerlendirilmesi, Su Tüketim, Arıtma, Yeniden Kullanım Sempozyumu, 3-5 Eylül 2008, 97, 2008.

14. KARACA G., TASDEMIR Y. Temporal and spatial variations in $\mathrm{PAH}$ concentrations in the sediment from the Nilufer Creek in Bursa, Turkey. Journal of Environmental Science and Health, Part A, 49 (8), 900, 2014.

15. GÜLERYÜZ G., ARSLAN H., ÇELIK C., GÜÇER Ş., KENDALL M. Heavy metal content of plant species along
Nilüfer stream in industrialized Bursa city, Turkey. Water, Air, and Soil Pollution, 195 (1-4), 275, 2008.

16. ÜSTÜN G.E. The assessment of heavy metal contamination in the waters of the Nilüfer stream in Bursa. Ekoloji, 81, 61, 2011.

17. WHO. Guidelines for drinking-water quality: fourth edition incorporating the first addendum. Geneva: World Health Organization; 2017. Licence: CC BY-NC-SA 3.0 IGO. http://www.who.int/water_sanitation_health/ publications/drinking-water-quality-guidelines-4including-1st-addendum/en/

18. AYERS R.S., WESTCOT D.W. Water quality for Agriculture. FAO Irrigation and Drainage Paper 29 Rev.1. Food and Agriculture Organization. Rome Italy. 1994.

19. BAHRI A. Present and future state of treated wastewaters and sewage sludge in Tunisia. Regional Seminar on Wastewater Reclamation and Reuse, 11-16 December, 1988, Cairo. 1988.

20. SADEGHI S., HARCHEGANI M.K., YOUNESI H. Suspended sediment concentration and particle size distribution, and their relationship with heavy metal content. Journal of earth system science, 121, 63, 2012.

21. NOLLET L.M., DE GELDER L. Handbook of water analysis. CRC Press. Boca Raton, FL. 2013.

22. WOLDETSADIK D., DRECHSEL P., KERAITA B., ITANNA F., GEBREKIDAN H. Heavy metal accumulation and health risk assessment in wastewaterirrigated urban vegetable farming sites of Addis Ababa, Ethiopia. International Journal of Food Contamination, 4 (1), 9, 2017.

23. PATEL P., RAJU N.J., REDDY B.S.R., SURESH U., SANKAR D.B., REDDY T.V.K. Heavy metal contamination in river water and sediments of the Swarnamukhi River Basin, India: risk assessment and environmental implications. Environmental Geochemistry and Health, 1-15, 2017.

24. LAKHERWAL D. Adsorption of heavy metals: a review. International Journal of Environmental Research and Development, 4 (1), 41, 2014.

25. KHAN Z.A, ASHRAF M., HUSSAIN A., MCDOWELL L. R. Seasonal variation of trace elements in a semiarid veld pasture. Communications in soil science and plant analysis, 37 (9-10), 1471, 2006.

26. PRASHANTH L., KATTAPAGARI, K.K., CHITTURI, R.T., BADDAM, V.R.R., PRASAD, L.K. A review on role of essential trace elements in health and disease. Journal of Dr. NTR University of Health Sciences, 4 (2), 75, 2015.

27. JAISHANKAR M., TSETEN, T., ANBALAGAN, N., MATHEW, B.B., BEEREGOWDA, K.N. 2014. Toxicity, mechanism and health effects of some heavy metals. Interdisciplinary toxicology, 7 (2), 60, 2014.

28. WONGSASULUK P., CHOTPANTARAT, S., SIRIWONG, W., ROBSON, M. Heavy metal contamination and human health risk assessment in drinking water from shallow groundwater wells in an agricultural area in Ubon Ratchathani province, Thailand. Environmental geochemistry and health, 36 (1), 169, 2014.

29. SU C.C. Heavy metal and cancer risk. SM Journal of Public Health and Epidemiology, 1 (4), 1019, 2015.

30. WANG Q., YANG, Z. Industrial water pollution, water environment treatment, and health risks in China. Environmental pollution, 218, 358, 2016.

31. SÖNMEZ, İ., KAPLAN, M., SÖNMEZ, S., Kimyasal gübrelerin çevre kirliliği üzerine etkileri ve çözüm 
önerileri. Batı Akdeniz Tarımsal Araştırma Enstitüsü Derim Dergisi, 25 (2), 24, 2008.

32. ALTIKAT A., TURAN T., TORUN F.E., BİNGÜL Z., Türkiye'de pestisit kullanımı ve çevreye olan etkileri. Atatürk Üniversitesi Ziraat Fakültesi Dergisi, 40 (2), 87, 2009.

33. AYDINALP C., FÜLEKY, G., TOLNER, L. The comparison study of some selected heavy metals in the irrigated and non-irrigated agricultural soils. Bulgarian Journal of Agricultural Sciences, 16 (6), 754, 2010.

34. GULCU-GUR B., TEKIN-OZAN, S., The Investigation of Heavy Metal Levels in Water and Sediment From Işıklı Lake (Turkey) in Relation to Seasons and Physico-
Chemical Parameters. Journal of Aquaculture Engineering and Fisheries Research, 3 (2), 87, 2017.

35. ISLAM M.S., AHMED, M.K., RAKNUZZAMAN, M., HABIBULLAH-AL-MAMUN, M., ISLAM, M.K. Heavy metal pollution in surface water and sediment: a preliminary assessment of an urban river in a developing country. Ecological Indicators, 48, 282, 2015.

36. MARCOVECCHIO J.E., BOTTÉ, S.E., DOMINI, C.E., FREIJE, R.H. Heavy Metals, Major Metals, Trace Elements. in Handbook of Water Analysis, 385, 2013.

37. SOU M.Y., MERMOUD, A., YACOUBA, H., BOIVIN, P. Impacts of irrigation with industrial treated wastewater on soil properties. Geoderma, 200, 31, 2013. 